\title{
Salt and Specific Ion Effects on Germination of Four Grass
}

\section{J. RYAN, S. MIYAMOTO, AND J. L. STROEHLEIN}

Highlight: The effects of $\mathrm{NaCl}, \mathrm{CaCl}_{2}, \mathrm{MgCl}_{2}, \mathrm{NaSO}_{4}, \mathrm{CaSO}_{4} \cdot 2 \mathrm{H}_{2} \mathrm{O}$, and $\mathrm{MgSO}_{4} \cdot 7 \mathrm{H}_{2} \mathrm{O}$ at concentrations of $50,100,150$, and $200 \mathrm{meq} / \mathrm{l}$ were studied on germination of the following range grasses: blue panicgrass (Panicum antidotale Retz.), Lehmann lovegrass (Eragrostis lehmanniana Nees.), Wilman lovegrass (E. superba Peyr.), and weeping lovegrass (E. curvula (Schrad.) Nees.). Increasing salt concentrations decreased germination. The extent of the decrease varied with the species and the type of salt. Inhibition was greatest with $\mathrm{Mg}$ and least with $\mathrm{Ca}$ salts. When $\mathrm{MgSO}_{4} \cdot 7 \mathrm{H}_{2} \mathrm{O}$ was used, the effect was less than the equivalent concentration of $\mathrm{MgCl}_{2}$. At equal osmotic pressures the effect of specific ions varied. Wilman and weeping lovegrasses were found to be relatively salt tolerant.

Economic viability of ranching depends largely upon increasing pasture output of extensive grazing areas. The introduction of nonindigenous grass species has been heralded as a major advance. Lovegrasses introduced from South Africa are good forage producers and suitable for the climatic conditions of the Southwest at lower elevations (Humphrcy, 1960). With good management, these grasses can be used for revegetation of depleted ranges as well as for prevention of soil erosion from embankments such as road and railways. Mine tailings have been revegetated successfully with some of these grasses (Ludeke, 1973). Blue panicgrass (Panicum antidotale Retz.) has been seeded extensively in Arizona (Anderson et al., 1957) and produces good forage yields under irrigation and exhibits drought tolerance under limited moisture conditions of desert grasslands (Wright, 1966). However, there are several factors associated with calcareous and alkaline soils of arid regions which impede widespread use of such species.

Salt accumulates during the natural soil forming processes, following waste disposal, and with poor irrigation

The authors are research associates and associate professor, respectively, Department of Soils, Water and Engineering, The University of Arizona, Tucson. Arizona Agr. Fxp. Station Journal No. 2263. This research was supported in part by the Arizona Mining Association.

Manuscript received February 21, 1974. management. Seed germination in salt-affected soils is influenced by the total concentration of dissolved salt (or the osmotic pressure) as well as by the type of salts involved. Hyder and Yasmin (1972) found that germination of alkali sacaton (Sporobolus airoides Torr.) was decreased by $\mathrm{MgCl}_{2}, \mathrm{KCl}$, $\mathrm{CaCl}_{2}, \mathrm{NaCl}$ and mannitol in order of decreasing magnitude, respectively. They concluded that the specific ion effect, especially the inhibitory effect of $\mathrm{Mg}$ was more important than the total salt effect for this species. The effects of salt and specific ions have agricultural crops (e.g., Allison, 1964; Gauch and Wadleigh, 1945; Wadleigh and Gauch, 1944), but little information is available regarding these effects for range grasses. An understanding of these relationships would promotc the general use of such grasses for revegetation. This paper presents the effects of $\mathrm{NaCl}, \mathrm{CaCl}_{2}$, $\mathrm{MgCl}_{2}, \mathrm{Na}_{2} \mathrm{SO}_{4}, \mathrm{MgSO}_{4}$, and $\mathrm{CaSO}_{4}$ on germination of four range grasses.

\section{Materials and Methods}

The following species of range grasses which are used for revegetation in Arizona were studied: blue panicgrass, Lehmann lovegrass (Eragrostis lehmannia Nees.), Wilman lovegrass (E. superba Peyr.), and weeping lovegrass (E. Curvula (Schrad.) Nees.). Seed was supplied by the Plant Materials Center of the Soil Conservation Service, Tucson, been investigated for several
Arizona. One hundred seeds of a species were placed on Whatman No. 42 filter paper in a sterile $9-\mathrm{cm}$ petri dish. For each species four replications were prepared for each salt solution. Ten milliliters of the proper salt solution were added by pipette to each dish. The salts used were $\mathrm{NaCl}, \mathrm{CaCl}_{2}$, $\mathrm{MgCl}_{2}, \mathrm{Na}_{2} \mathrm{SO}_{4}, \mathrm{MgSO}_{4} \cdot 7 \mathrm{H}_{2} \mathrm{O}$ and $\mathrm{CaSO}_{4} \cdot 2 \mathrm{H}_{2} \mathrm{O}$. Solution concentrations in each salt were $50,100,150$, and $200 \mathrm{mcq} / \mathrm{litcr}$ with the exception of $\mathrm{CaSO}_{4} \cdot 2 \mathrm{H}_{2} \mathrm{O}$, which had a concentration of approximately 30 $\mathrm{meq} / \mathrm{liter}$ due to its limited solubility. Distilled water was used as a control solution for germination of each species. The experiment was conducted at a constant temperature of $27^{\circ} \mathrm{C}$ with fluorescent lighting provided for 10 hours daily. The seeds were incubated for 12 days when approximately $80 \%$ or more of the controls for each species had germinated. Seeds were considered to be germinated if the plumule was larger than the seed and visible to the naked eye. During the incubation period evaporation occurred from the petri dishes resulting in an increase in salt concentration, excepting $\mathrm{CaSO}_{4} \cdot 2 \mathrm{H}_{2} \mathrm{O}$.

\section{Results}

The germination percentages $(\mathrm{P})$ of the four grass species are plotted against the initial concentration (C) in Figure 1. Germination generally decreased with increasing salt concentration and the degree of reduction varied with the salt and grass species. When chloride was used as an anion (Fig. 1 , solid lines) $\mathrm{Mg}$ and $\mathrm{Na}$ restricted germination much more severely than equivalent concentrations of $\mathrm{Ca}$. The inhibitory effect of $\mathrm{Mg}$ and $\mathrm{Na}$ was particularly pronounced in blue panicgrass and Lehmann lovegrass. No adverse effect was found on germination of weeping lovegrass even at the highest concentrations of $\mathrm{CaCl}_{2}$. The effect of 

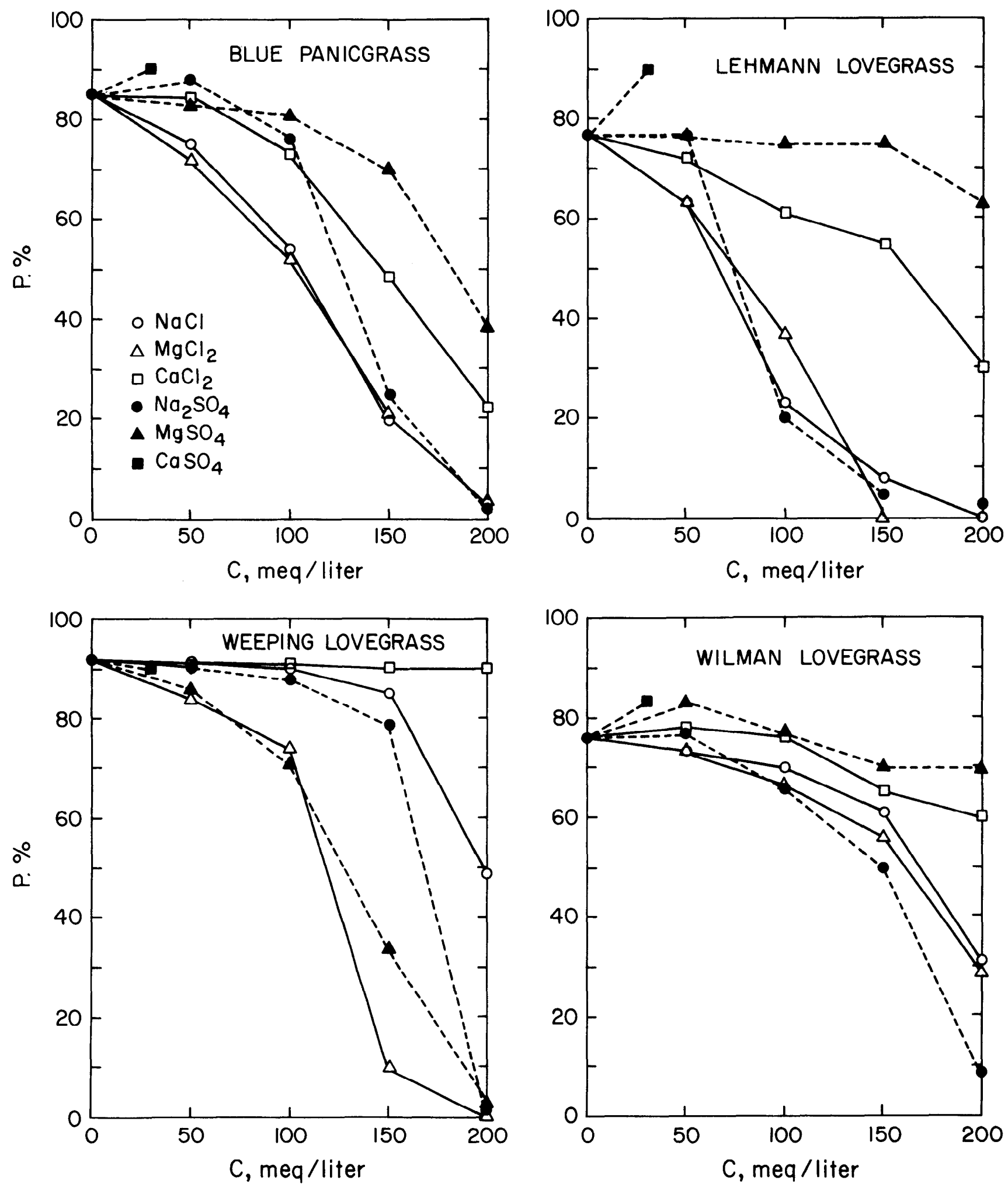

Fig. 1. Effect of salt concentration $(C)$ on germination percentage $(P)$ of four range grass species.

increasing concentration of this salt on Wilman lovegrass was slight. When sulfate was used as an anion (Fig. 1, dotted line) the inhibitory effect of $\mathrm{Mg}$, but not $\mathrm{Na}$, was ameliorated for all species with the exception of weeping lovegrass. The saturated solution of $\mathrm{CaSO}_{4} \cdot 2 \mathrm{H}_{2} \mathrm{O}$ had a stimulating effect on germination in three of the four species.

Tolerance of grass species to salt stress showed marked differences. As a measure of the tolerance, the salt concentration that reduced germination by 20 and $50 \%$ of the salt free condition is listed in Table 1. The larger concentration of salts indicate higher tolerance by grass species. Hyder and Yasmins' (1972) data for alkali sacaton are also included. Their experimental condition was somewhat different from ours but the value relative to the salt free condition can be used for comparative purposes. 

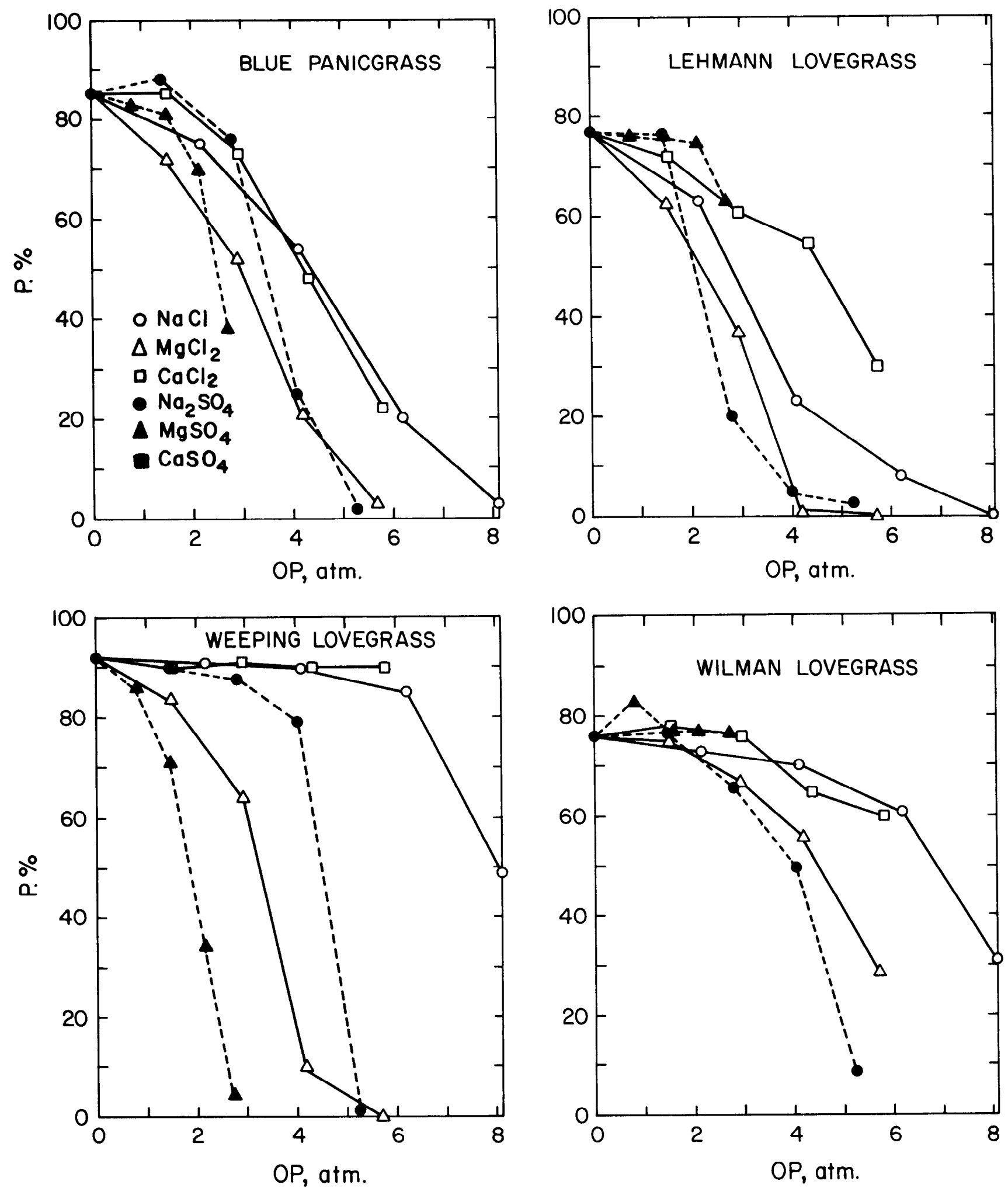

Fig. 2. Percent germination ( $P$ ) of four range grass species as a function of osmotic pressure (OP).

Blue panic and Lehmann lovegrass were sensitive to $\mathrm{MgCl}_{2}$ and $\mathrm{NaCl}$ at both 20 and $50 \%$ germination reduction levels. Weeping lovegrass was sensitive to $\mathrm{MgCl}_{2}$ and $\mathrm{MgSO}_{4}$ while Wilman lovegrass was sensitive to $\mathrm{MgCl}_{2}$ and $\mathrm{Na}_{2} \mathrm{SO}_{4}$.
It is convenient for most practical purposes to express the germination percentage as a function of salt concentration. It is, however, not suited for expressing what commonly is referred to as "specific ion effect." The germination percentage (P) was thus replotted against the conventional osmotic pressure (OP) in Figure 2. There was a large difference in germination percentage between ion species especially in weeping lovegrass at equal osmotic pressures. The least effect was usually caused by $\mathrm{CaCl}_{2}$, 
Table 1. Salt concentrations (meq/liter) needed to reduce germination by 20 and $50 \%$ of salt free condition.

\begin{tabular}{lrrrrr}
\hline \hline $\begin{array}{l}\text { Species and } \\
\text { reduction }\end{array}$ & $\mathrm{NaCl}$ & $\mathrm{MgCl}_{2}$ & $\mathrm{CaCl}_{2}$ & $\mathrm{Na}_{2} \mathrm{SO}_{4}$ & $\mathrm{MgSO}_{4}$ \\
\hline $\begin{array}{l}\text { 20\% Reduction } \\
\text { Alkali Sacaton* }\end{array}$ & 41 & - & & & - \\
$\quad$ Blue Panicgrass & 62 & 54 & 105 & 106 & 150 \\
Lehmann Lovegrass & 53 & 54 & 100 & 64 & 200 \\
Weeping Lovegrass & 165 & 100 & $>200$ & 153 & 90 \\
$\quad$ Wilman Lovegrass & 150 & 127 & 190 & 115 & 200 \\
50\% Reduction & & & & & \\
Alkali Sacaton* & 113 & - & - & - & - \\
Blue Panicgrass & 116 & 114 & 161 & 132 & 192 \\
Lehmann Lovegrass & 81 & 97 & 184 & 83 & $>200$ \\
Weeping Lovegrass & 200 & 122 & $>200$ & 171 & 133 \\
$\quad$ Wilman Lovegrass & 187 & 182 & $>200$ & 164 & $>200$ \\
\hline
\end{tabular}

*Data of Hyder and Yasmin (1972).

while $\mathrm{MgCl}_{2}$ and $\mathrm{Na}_{2} \mathrm{SO}_{4}$ had inhibitory effects at equal pressures. The effect of sulfate became obscure using this scale.

\section{Discussion}

The present experiment clearly demonstrates that germination of range grass species is influenced not only by the salt concentrations (or the osmotic pressure) but also by the nature of the ions in the salt solutions. The marked differences in germination as influenced by ion species at the same osmotic pressures points to shortcomings in the hypothesis that the rate of germination is solely controlled by the osmotic pressure of solutes or by the gradient by which water moves into seeds. Specific ion effects are interpreted in terms of an influence on the physiological processes that regulate germination. For instance, the role of $\mathrm{Ca}$ in relation to protoplasm and selective ion transport through cell membranes of plant roots has been shown by Epstein (1961). Hyder and Yasmin (1972) also offer some discussion on specific ion effect of $\mathrm{MgCl}_{2}$ on seed germination. The detailed mechanism of specific ion effects at the germination stage is, however, still poorly understood.

The value of the present experimental data is of practical significance. In alkali or sodic soils, sodium is the dominant cation in association with chloride, sulfate, or to a lesser degree, bicarbonate. The germination percentage as affected by $\mathrm{Na}$ salts is therefore of particular interest. Though values varied with the accompanying anions, weeping and Wilman lovegrasses were more tolerant than blue panicgrass and Lehmann lovegrass for either chloride or sulfate and more tolerant than alkali sacaton for $\mathrm{NaCl}$. The results indicate that weeping and Wilman lovegrasses could be successfully germinated on soils having high levels of $\mathrm{Na}$, which may inhibit germination of other species.

In saline soils, the composition of the ions in solution is mixed. Although $\mathrm{Na}$ or $\mathrm{Ca}$ is usually the dominant cation in saline soils, some soils arc derived from parent material containing high levels of $\mathrm{Mg}$ which may be unfavorable for most grasses. In order to evaluate specific ion effects consideration must be given to coexisting anions and cations occurring as mixed salts. Hyder and Yasmin (1972) found a somewhat less detrimental effect of $\mathrm{Mg}$ when $\mathrm{Na}$ or $\mathrm{Ca}$ coexist with $\mathrm{Cl}$ as an anion. Similarly, La Haye and Epstein (1969) found an ameliorating effect of $\mathrm{Ca}$ in the presence of toxic levels of $\mathrm{Na}$. This could conceivably occur for the grass species tested here. Furthermore, the inhibitory effect of $\mathrm{Mg}$ salts varies with associated anion species.

Land area salinized by excessive waste disposal is increasing. The germination of tested grass species in soils contaminated by $\mathrm{MgCl}_{2}$ or $\mathrm{Na}_{2} \mathrm{SO}_{4}$ would be less than in areas contaminated by $\mathrm{CaCl}_{2}$ disposal at similar concentrations. Areas that are influenced by the discharge of gaseous contaminants are also increasing. In the Southwest, for instance, large acreages of land have been subjected to $\mathrm{SO}_{2}$ emission. The discharged $\mathrm{SO}_{2}$ reacts in the atmosphere or is directly absorbed by soils and plants. Since the soils in this region are mostly calcareous, the continuous discharge of $\mathrm{SO}_{2}$ eventually results in high levels of soluble $\mathrm{Ca}$. This process is not likely to cause reduction in seed germination but could enhance it in alkali soils. It could have an impact in altering relative growth among grass species in the native condition.

Germination of range grass is influenced by several interrelated factors. Though working with a somewhat different species of grass others have shown that response varies with moisture conditions in the soil (McGinnies, 1960) and with temperature of germination (Knipe, 1967; McGinnies, 1960). Successful field adaptation of range grasses requires a consideration of these variables. The conclusion to be drawn from this experiment is that both salt and specific ion effects are important and vary with the species of grass used. This information provides some basis for selection of plant species for native soil conditions or where the salt composition is altered by management practices.

\section{Literature Cited}

Allison, L. E. 1964. Salinity in relation to irrigation. Adv. in Agron. 16:139-179.

Anderson, D., L. P. Hamilton, H. G. Reynolds, and R. R. Humphrey. 1957. Reseeding desert grassland ranges in southern Arizona. Arizona Agr. Exp. Sta. Bull. 249. 31 p.

Epstein, E. 1961. The essential role of calcium in selective cation transport by plant cells. Plant Physiol. 26:437-444.

Gauch, H. G., and C. H. Wadleigh. 1945. Effect of high concentrations of sodium, calcium, chloride and sulfate on ionic absorption by bean plants. Soil Sci. 59:139-153.

Humphrey, R. R. 1960. Arizona range grasses, their description, forage value, and management. Arizona Agr. Exp. Sta. Bull. 298. 104 p.

Hyder, S. Z., and S. Yasmin. 1972. Salt tolerance and cation interaction in alkali sacaton at germination. J. Range Manage. 25:390-392.

Knipe, O. D. 1967. Influence of temperature on the germination of some range grasses. J. Range Manage. 20:298-299.

LaHaye, P. A., and E. Epstein. 1969. Salt toleration by plants; enhancement with calcium. Science 166:395-396.

Ludeke, K. L. 1973. Vegetative stabilization of tailings disposal berms. Mining Congr. J. 59:32-39.

McGinnies, W. J. 1960. Effects of moisture stress and temperature on germination of six range grasses. Agron. J. 52:159-162.

Wadleigh, C. H., and H. G. Gauch. 1944. The influence of high concentrations of sodium sulfate, sodium chloride, calcium chloride, and magnesium chloride on the growth of guayule in sand culture. Soil Sci. 58:399-403.

Wright, L. N. 1966. Blue panicgrass for Arizona and the Southwest. Arizona Agr. Exp. Sta. Tech. Bull. 173. 27 p. 